\title{
Effect of Rice Husk Silica Nanoparticles on Rice (Oryza sativa L.) Seed Quality
}

\author{
Nita Babaso Patil ${ }^{1 *}$, H. Sharanagouda ${ }^{1}$, S.R. Doddagoudar ${ }^{2}$, \\ C.T. Ramachandra ${ }^{3}$ and K.T. Ramappa ${ }^{1}$
}

${ }^{1}$ Department of Processing and Food Engineering, ${ }^{2}$ Department of Seed Science and Technology, University of Agricultural Sciences, Raichur- 584104 (Karnataka), India ${ }^{3}$ Department of Agricultural Engineering, College of Agriculture, GKVK, Bengaluru-560065 (Karnataka), India

*Corresponding author

\section{A B S T R A C T}

\begin{tabular}{|l|}
\hline K e y w o r d s \\
$\begin{array}{l}\text { Silica nanoparticles, } \\
\text { Seed quality, Seed } \\
\text { borne fungi, Rice } \\
\text { seed, Rice husk }\end{array}$ \\
\hline Article Info \\
\hline $\begin{array}{l}\text { Accepted: } \\
\text { 24 November } 2018 \\
\text { Available Online: } \\
\text { 10 December } 2018\end{array}$ \\
\hline
\end{tabular}

Seed quality is critical factor for seed germination and plant development. This study was carried out by priming of rice seeds with different concentrations $(0,25,50,75,100,125$, 150,175 and $200 \mathrm{ppm}$ ) of biosynthesized silica nanoparticles. Silica nanoparticles (93.14 $\mathrm{nm}$ ) were biosynthesized by using rice husk as waste material. Result showed concentration dependent response of seed quality parameters and $125 \mathrm{ppm}$ concentration of silica nanoparticles resulted significantly higher seed quality parameters as improved in seed germination (up to $10 \%)$ over control and root length $(14.80 \mathrm{~cm})$, shoot length $(5.65$ $\mathrm{cm})$, seedling length $(20.45 \mathrm{~cm})$, seedling dry weight $(106.98)$, seedling vigour index-I (1891), seedling vigour index-II (9895), peak value (20.50), speed of germination (26.86) and mean germination time (3.55 day) also, significantly positive response was recorded to control seed borne fungi in one month stored primed rice seeds with silica nanoparticles. The lowest infection level $(5.13 \%)$ of seed borne fungi was observed in 200 ppm which was significantly on par to $(5.53 \%)$ at $175 \mathrm{ppm}$ and highest per cent infection level was recorded in control $(9.67 \%)$. The priming method with silica nanoparticles had favourable effect on rice seed germination and seedling early growth.

\section{Introduction}

The nanotechnology attracted much attention due to unique physico-chemical properties of nanoparticles as compare to their bulk form (Monica and Cremonini, 2009). Biosynthesis of nanoparticles involves an environment friendly green chemistry based an approach to synthesis nanoparticles (NPs) by using unicellular and multicellular biological entities such as actinomycetes, bacteria, fungi, plants, viruses, yeast and agriculture waste materials (Vithiya and Sen, 2011). Among the latest line of technological innovations in the field of agriculture, nanotechnology occupies a distinguished position in remodelling agriculture and food production to fulfil the demands in an efficient and cost effective way. 
Silica nanoparticles (SNPs) have gained a greater attention because of its highly reactive surface area to volume ratio, chemical and physical stability, low toxicity and straight forward surface chemistry (Ghorbani et al., 2015). It is frequently used in industrial manufacturing, packaging, ceramic, synthesis of high molecule composites material, drug delivery, cancer therapy, disease labelling, biosensor, food and agriculture (Sahoo et al., 2007; Kasaai, 2015).

High quality seed is the basic and critical input that acts as key factor for successful agriculture. Recently, some chemical materials were intensely used for improvement of seed quality and speed up the seed germination such as gibberellic acid, calcium, ethanol and ascorbic acid (Zhu et al., 2010). Applications of some nanomaterial can help faster seed germination which would help in high yield with reduced environmental impact as compared with the traditional methods (Khot et al., 2012). However, Harris, (1996) reported that penetration of NPs during treatment period, enhancing their functionality and throughout growth.

Rice plant is known as a typical silica plant, which absorbs greater quantity of silicon as compare to other cereals. However, excessive use of fertilizers, increasing incidence of pests, microbes and insufficient amounts of water causes the depletion of silicon in soil leading to decline in rice production. The hydrophilic nature of silicon facilitate water uptake and its transportation in plant leaves. It was reported that silicon helps to enhance the stability of lipids in cell membrane and prevent the structural and functional deterioration of cell membrane of rice plant when it exposed to environment stress (Agarie et al., 1998). Silicon play vital role in promoting the number of panicles, grain filling, grain yield and quality of rice (Savant et al., 1997). The previous researchers have shown the seed priming technique may improve the seed germination process such as dormancy breaking imbibitions, hydrolysis or mobilization of inhibitors and enzyme activation (Asgedom and Becker, 2001).

The various beneficial effects of SNPs on seed quality parameters have been reported. Azimi et al., (2014) reported application of SNPs significantly increased $86.30 \%$ seed germination of tall wheatgrass in 40 of SNPs. At $40 \mathrm{mg} \mathrm{L}^{-1}$ root $(15.00 \%)$, shoot weights $(14.60 \%)$, seedling weight $(53.60 \%)$ and seedling length $(47.20 \%)$ were increased and decreased under 60 and $80 \mathrm{mg} \mathrm{L}^{-1}$ and the highest values percent seed germination $(22.16 \%)$ and seedling vigour index $(507.82 \%)$, seed germination index $(22.15 \%)$ of tomato seed was recorded at $8 \mathrm{~g} \mathrm{~L}^{-1}$ of SNPs (Siddiqui and Al-Whaibi, 2014). An increased in germination may be due to the absorption and utilization of SNPs by seeds (Suriyaprabha et al., 2012). Highest germination (57 and $41.5 \%$ ) and lowest mean germination time (6 and 5.7 days) of scarified seeds of Astragalus squarrosus in field condition reported at 40 and $60 \mathrm{mg} \mathrm{L}^{-1}$ of SNPs respectively (Azimi et al., 2016). Sharifi-Rad et al., (2016) suggested the lower concentrations of SNPs present positive aspects, concentrations of SNPs should be optimized for each crop (a narrower range of 10 to $1000 \mathrm{mg} \mathrm{L}^{-1}$ ) in a bid to maximize the yield.

Seed borne disease of rice cause considerable yield losses in rice growing regions. In India, Helminthosporium oryzae, Curvularia lunta, Cochlobolus lunatus, Alternaria tenusi and Epicoccum sp. H. oryzae, are major seed born fungus of rice (Alam et al., 2014). Seed borne fungi are mainly managed by synthetic fungicides which causing pollution of soil and water (Nostro et al., 2000). Therefore, developing efficacious and prophylactic seed disinfection methods using safe active 
ingredients is an important research area. Nanoparticles has been considered an alternative and effective approach which is eco-friendly, low cost and effective for control of seed borne fungi as well as enhanced quality and quantity of plant production (Khan and Rizvi, 2014).

In view of importance of SNPs in seed quality and seedling growth of rice plant, this study was conducted to assess the effect of different concentrations of biosynthesized silica nanoparticles on rice seed quality parameters by priming technique. The use of rice husk as source of SNPs has both positive environmental and economic impact through the use of an abundant low-value agricultural by-product that can alleviate waste disposal problems.

\section{Materials and Methods}

\section{Biosynthesis of silica nanoparticles}

Silica nanoparticles were biosynthesized from rice husk at the optimized conditions according to the methods described by Rafiee et al., (2012). Rice husk was pre-treated with $1 \mathrm{~N} \mathrm{HCl}$ then subjected to heat treatment in muffle furnace at $700{ }^{\circ} \mathrm{C}$ for $2 \mathrm{~h}$ to obtain the ash. $20 \mathrm{~g}$ ash was stirred in a $160 \mathrm{ml}$ of $2.5 \mathrm{M}$ $\mathrm{NaOH}$ solution. The solution was heated in a covered beaker and filtered through filter paper. The obtained viscous, transparent and colourless filtrate solution was allowed to cool at room temperature and $10 \mathrm{M} \mathrm{H}_{2} \mathrm{SO}_{4}$ was then added under constant stirring at controlled conditions until it reached to $\mathrm{pH} 2$, then $\mathrm{NH}_{4} \mathrm{OH}$ was used to adjust $\mathrm{pH}$ level up to 8.5 and was allowed to stand at room temperature for $3 \mathrm{~h}$. White silica participate was washed repeatedly with the distilled water until the filtrate was completely free from alkali. Silica nanoparticles were prepared by using refluxing of obtained silica with $6 \mathrm{M}$ $\mathrm{HCl}$ for $4 \mathrm{~h}$ and washed repeatedly using distilled water to make it acid free. Then it was dissolved in $2.5 \mathrm{M} \mathrm{NaOH}$ by continuous stirring and $\mathrm{H}_{2} \mathrm{SO}_{4}$ was added until it reached to $\mathrm{pH}$ 8. The precipitated silica was washed repeatedly with warm distilled water to make it alkali free and then dried in the hot air oven at $50{ }^{\circ} \mathrm{C}$ for $48 \mathrm{~h}$.

\section{Characterization of Biosynthesized Silica Nanoparticles}

Biosynthesized silica nanoparticles have been characterized by using Zetasizer (Malvern, ZETA Sizer, nano383 issue 5.0, England), Xray diffraction (Theta-theta type $\mathrm{X}$-ray diffractometer, Rigaku corporation, Japan) and scanning electron microscope (Carl Zeiss Microscopy, EVO 10, Germany) to identify its average particle diameter and morphology.

\section{Seed treatments}

Rice seeds (var, BPT-5204) were collected from seed unit, UAS campus, Raichur, Karnataka, India. Silica nano powder was dispersed at different concentrations $\left(25,50,75,100,125,150,175\right.$ and $200 \mathrm{mg} \mathrm{L}^{-}$ ${ }^{1}$ ) in de-ionized water by continuous stirring for a period of $10 \mathrm{~min}$. The priming of rice seeds was carried out by soaking seeds for $12 \mathrm{~h}$ with seed to solution ratio of $1: 5\left(\mathrm{~g} \mathrm{~L}^{-1}\right)$ (Farooq et al., 2006). The control was used as without SNPs i.e., seed treated with de-ionized water.

\section{Measurement of seed quality parameters}

Seed germination test was carried out by between paper methods as prescribed by International Seed Testing Association (ISTA), (2013). The four replications of randomly counted 100 seeds were placed on the germination paper in a zig-zag manner. The rolled towels with seeds were secured at both ends with the rubber bands and placed in 
the walk in seed germination chamber maintained at a constant temperature of $25 \pm 2^{\circ} \mathrm{C}$ and $90 \pm 5 \%$ relative humidity. The germination was recorded on $14^{\text {th }}$ day based on normal seedling germination. Per cent seed germination, root length, shoot length, seedling length and seedling dry weight were recorded as per ISTA procedures. Seedling vigour index-I and II were computed using the formula (Abdul-Baki and Anderson, 1973).

Seedling vigour index-I $=$ Germination percentage $\times$ Mean length of seedling

Seedling vigour index-II $=$ Germination percentage $\times$ Mean seedling dry weight

The set of germination for daily count used to calculated peak values using below given formula suggested by Gairola et al., (2011).

Peak value $=\frac{\text { Highest seed germinated }}{\text { No. of day s }}$

The speed of germination (germination rate) was calculated by dividing the number of normal seedling per 100 seeds obtained at each counting in standard germination test by number of days seed has been in germinator (Maguire, 1962).

Speed of germination $=\frac{G_{1}}{D_{1}}+\frac{G_{2}}{D_{2}}+\ldots \ldots \ldots \ldots+\frac{G_{n}}{D_{n}}$

Where $G_{1}, G_{2}$, - - $-G_{n}$ are no. of seeds germinated on day $D_{1}, D_{2},---D_{n}$

The mean germination time was calculated using following formula described by Demir et al., (2008)

Mean germination time $=\frac{\mathrm{N}_{1} \mathrm{~T}_{1}+\mathrm{N}_{2} \mathrm{~T}_{2}+\ldots . .+\mathrm{NnTn}}{\mathrm{N}_{1}+\mathrm{N}_{2}+\ldots . .+\mathrm{Nn}} \times$

Where $\mathrm{Nn}$ is number of seeds germinated at time Tn and, Tn is days from the beginning of the germination test.

\section{Seed borne fungi}

Seed health testing for fungal infection was carried out using blotter technique. It was carried out after one month stored primed rice seeds with different concentrations of silica nanoparticles. Twenty five seeds were placed equidistantly on moistened blotter taken in sterilized pertriplate. The treated sample were placed in cabinet type seed germinator by maintaining a constant temperature of $25 \pm 1^{\circ} \mathrm{C}$ and the relative humidity of $90 \pm 2 \%$. On $14^{\text {th }}$ day, plates were examined under stereo binocular microscope for the presence of seed borne fungi. The infection level and occurrence of seed borne fungi of seeds were counted and expressed in percentage using following formulae described by Mahmoud et al., (2013).

Infection level $(\%)=\frac{\text { Total No. of infected seeds }}{\text { Total No.tested seeds }} \times 100$

\section{Statistical analysis}

Each treatment was conducted with four replicates and obtained data were analysed by using completely randomized design. The results were presented as means \pm Standard Error (SE). Analysis of Variance (ANOVA) and Duncan's Multiple Range Test (DMRT) method were used to exam the means between treatments and then statistically significant differences between means by using SPSS software version 16.0 at $P \leq 0.01$.

\section{Results and Discussion}

Characterization of biosynthesized silica nanoparticles

Zetasizer revealed an average particle diameter of biosynthesized silica nanoparticles was $93.14 \mathrm{~nm}$ (Figure 1). X-ray diffraction pattern showed broad halo band of absorbance at about $2 \theta=15-25^{\circ}$ region which confirms 
the amorphous nature (Figure 2) and SEM image revealed that uniformly distributed biosynthesized silica nanoparticles were in the agglomerated with spherical morphology (Figure 3).

\section{Effect of SNPs on seed germination}

The effect of different concentrations of SNPs on seed germination is presented in Table 1 . SNPs had non-significant effect on germination with $25-75 \mathrm{ppm}$ and $100-200 \mathrm{ppm}$ caused significantly positive germination in comparison to the control.

The significantly higher per cent seed germination $(98.75 \%)$ was recorded in 125 ppm of SNPs compared to all other concentrations and control $(88.50 \%)$, which showed $10.38 \%$ increased over the control. The increased in germination percentage are in good agreement with the results of (Siddiqui and Al-Whaibi, 2014; Lu et al., 2015) who reported that $5 \mathrm{~g} \mathrm{~L}^{-1}$ of SNPs increased tomato seed germination by approximately $10 \%$ and $22 \%$ compared to control. The variation in concentrations might be due to the uptake, translocation and accumulation of nanoparticles (NPs) which depends on specific properties of NPs (size, surface area, morphology, chemical composition, reactivity and stability), concentrations, plant species, plant tissues and growth stages (Castiglione et al., 2011; Adhikari et al., 2013). The improvement of germination in primed seeds with SNPs might be due to the imbibitions of water into seeds and activation of considerable enzymes synthesis which are responsible for driving many metabolic reaction to increases in seed germination (Senthilkumar, 2011; Janmohammadi and Sabaghnia, 2015). Photosynthesis is termed as photo and enzyme catalyzed chemical reaction. The plasmon effect can increase the generation of electrons inside the photosynthetic complex, NPs should enhance the absorption, electron transport rate, oxygen evolution rate, transforming of light energy into chemical energy, and photophosphorylation activity etc (Das and Debnath, 2017.).

The per cent germination was declined after $125 \mathrm{ppm}$ but it was higher as compare to the control. Results were in conformity with molybdenum NPs in rice (Adhikari et al., 2013) and SNPs in Astragalus squarrosus seed (Azimi et al., 2016). The present findings of decreased in germination in higher concentration level of SNPs might be due to accumulation of silicon around the seed in the epidermal tissues and a layer of cellulose membrane-Si is created when calcium and pectin ions are present, which can increase sustainability of cell wall by forming a layer and it can partly delay radicle emergence (Janmohammadi and Sabaghnia, 2015; Sahebi et al., 2015). However, appropriate application of concentration of SNPs could increase cell extension by formatting complexes of $\mathrm{Si}$ polyphenol or substitution of $\mathrm{Si}$ and lignin which facilitate cell wall loosening to increase the seed germination (Dragisic et al., 2007).

\section{Effect of SNPs on root and shoot length}

The non-significant effect on root and shoot lengths were observed in 25-100 ppm and 25$50 \mathrm{ppm}$, respectively as compare to control. The concentrations $125 \mathrm{ppm}$ and $200 \mathrm{ppm}$ recorded $18.30 \%$ and $10.69 \%$ increased in root length, respectively over control. Therefore, root elongation of plant species would have a dose dependent response. Since roots are the first target tissue to confront with excess concentrations of pollutants, toxic symptoms seem to appear more in roots rather than in shoots. The presence of SNPs on the root surface could alter the surface chemistry of the root which is depends on the how the roots interact with their environment. 
The shoot length increased to $30.64 \%$ in 125 ppm concentration over the control. In 200 $\mathrm{ppm}$ of concentration of SNPs, $26.26 \%$ increased in shoot length over the control was observed with $6.30 \%$ decreased over the treatment of $125 \mathrm{ppm}$. Azimi et al., (2014) reported the application of $40 \mathrm{mg} \mathrm{L}^{-1}$ of SNPs largely increased seedling, root and shoot elongation of tall wheatgrass as compared to the control. Adhikari et al., (2013) reported the maximum germination $(100 \%)$, shoot length $(96 \mathrm{~cm})$ and root length $(141 \mathrm{~cm})$ at 40 ppm of SNPs and $5 \mathrm{ppm}$ of molybdenum (Mo) NPs affected positive germination (94\%), shoot length (121 $\mathrm{cm})$ and root length $(155 \mathrm{~cm})$ for rice seedlings. Beyond this concentration, the growth was inhibited in case of Mo NPs due the accumulation and uptake of these NPs by the roots. In this study. The higher concentrations (150-200 ppm) showed adverse effect on the seedling length over the 125 ppm, this might be due to excess absorption of the NPs which resulted from penetration of NPs in to shoot and root cell wall and plasma membrane of epidermal layers and accumulation in vascular tissues thereby affected cell division and cell elongation (Korishettar et al., 2016). Thus, the SNPs, may play vital role for improvement in seed germination characteristics, it may be easily visualised with their direct and indirect involvement in the root and shoot length.

\section{Effect of SNPs on seedling length and seedling dry weight}

The $125 \mathrm{ppm}$ of SNPs showed $21.88 \%$ increased in seedling length and $5.66 \%$ in seedling dry weight as compare to control. The Pearson's correlation coefficient confirmed the positive linear relationship $(\mathrm{r}=0.98)$ for seedling length and seedling dry weight. The $200 \mathrm{ppm}$ of SNPs registered $3.37 \%$ increased of seedling dry weight over the control and $2.4 \%$ decrease over the treatment of $125 \mathrm{ppm}$. The probable reason for increasing seedling length might be due to their increased chemical reactivity which acts as cofactors of enzymes involved in germination ultimately leading to better seedling growth. The exogenous SNPs application might have improved seed germination and seedling growth by enhancing antioxidant defence and improvement in iron nutrition (Shi et al., 2014) also, increased in organic compounds such as proteins, phenols and chlorophyll in maize plants was observed due to SNPs treatment (Suriyaprabha et al., 2012). The declined in seedling length and dry weight were observed beyond the $125 \mathrm{ppm}$, which might be indication of phytotoxic effects of higher concentrations of SNPs on rice seedlings over the superior treatment concentration.

\section{Effect of SNPs on seedling vigour index- I and II}

The vigour index reveals the germination capacity and growing tendency of seedling (Deng et al., 2014). The decrease in vigour of seeds slows the plant's growth rate, reducing crop yields (Zheng et al., 2005). The nonsignificant effect on seedling vigour index-I and II were observed in 25-75 ppm and 25$100 \mathrm{ppm}$, respectively as compare to control. The maximum seed vigour index-I and II were recorded in $125 \mathrm{ppm}$ of SNPs, which were $29.96 \%$ and $15.49 \%$ over the control respectively. The vigour enhancement by incorporation of SNPs through seed priming might be due to increased cell division within the apical meristem of seedling (Janmohammadi and Sabaghnia, 2015) and the Pearson's correlation coefficients showed positive linear relationship between per cent seed germination and seedling vigour index-I and II. Overall improvement in seed vigour might be due to improvement in germination and seedling growth characteristics (Feizi et al., 2013). 
Table.1 Effect of SNPs on seed quality parameters of rice (Oryza sativa L.) seed

\begin{tabular}{|c|c|c|c|c|c|c|c|}
\hline $\begin{array}{l}\text { Concentrations } \\
\text { of SNPs (ppm) }\end{array}$ & $\begin{array}{c}\text { Seed germination } \\
(\%)\end{array}$ & $\begin{array}{l}\text { Root Length } \\
\text { (cm) }\end{array}$ & $\begin{array}{l}\text { Shoot Length } \\
\text { (cm) }\end{array}$ & $\begin{array}{l}\text { Seedling Length } \\
\qquad(\mathrm{cm})\end{array}$ & $\begin{array}{c}\text { Seedling Dry } \\
\text { Weight } \\
\text { (mg) }\end{array}$ & $\begin{array}{c}\text { Vigour Index- } \\
\text { I }\end{array}$ & $\begin{array}{c}\text { Vigour Index- } \\
\text { II }\end{array}$ \\
\hline $\mathbf{0}$ & $88.50 \pm 1.16^{\mathrm{d}}$ & $15.13 \pm 0.64^{d}$ & $5.25 \pm 0.46^{\mathrm{b}}$ & $20.38 \pm 0.81^{\mathrm{f}}$ & $105.85 \pm 0.99^{d}$ & $1805 \pm 78.82^{\mathrm{g}}$ & $9364 \pm 139.21^{d}$ \\
\hline 25 & $88.75 \pm 1.16^{\mathrm{d}}$ & $15.26 \pm 0.64^{\mathrm{d}}$ & $5.38 \pm 0.46^{\mathrm{b}}$ & $20.63 \pm 0.81^{\text {fef }}$ & $106.00 \pm 0.99^{d}$ & $1830 \pm 78.82^{g f}$ & $9410 \pm 139.21^{\mathrm{d}}$ \\
\hline 50 & $89.00 \pm 1.16^{\mathrm{d}}$ & $15.63 \pm 0.64^{d}$ & $6.35 \pm 0.46^{\mathrm{ab}}$ & $21.98 \pm 0.81^{\text {fdef }}$ & $106.45 \pm 0.99^{\mathrm{cd}}$ & $1961 \pm 78.82^{\text {efg }}$ & $9474 \pm 139.21^{d}$ \\
\hline 75 & $89.50 \pm 1.16^{\mathrm{cd}}$ & $16.01 \pm 0.64^{\mathrm{dcd}}$ & $6.83 \pm 0.46^{\mathrm{a}}$ & $22.84 \pm 0.81^{\text {fcde }}$ & $108.35 \pm 0.99^{\mathrm{bcd}}$ & $2044 \pm 78.82^{\text {def }}$ & $9697 \pm 139.21^{d}$ \\
\hline 100 & $92.75 \pm 1.16^{b c}$ & $16.35 \pm 0.64^{\mathrm{dbcd}}$ & $7.08 \pm 0.46^{\mathrm{a}}$ & $23.43 \pm 0.81^{\mathrm{tbcd}}$ & $109.15 \pm 0.99^{b c}$ & $2171 \pm 78.82^{\text {cde }}$ & $10121 \pm 139.21^{\mathrm{c}}$ \\
\hline 125 & $98.75 \pm 1.16^{\mathrm{a}}$ & $18.52 \pm 0.64^{\mathrm{a}}$ & $7.57 \pm 0.46^{\mathrm{a}}$ & $26.09 \pm 0.81^{\mathrm{ta}}$ & $112.20 \pm 0.99^{\mathrm{a}}$ & $2576 \pm 78.82^{a}$ & $11079 \pm 139.21^{\mathrm{a}}$ \\
\hline 150 & $95.25 \pm 1.16^{b}$ & $18.14 \pm 0.64^{\mathrm{ab}}$ & $7.52 \pm 0.46^{\mathrm{a}}$ & $25.61 \pm 0.81^{\mathrm{fab}}$ & $110.80 \pm 0.99^{\mathrm{ab}}$ & $2439 \pm 78.82^{\mathrm{ab}}$ & $10556 \pm 139.21^{b}$ \\
\hline 175 & $94.50 \pm 1.16^{\mathrm{b}}$ & $17.73 \pm 0.64^{\mathrm{abc}}$ & $7.40 \pm 0.46^{\mathrm{a}}$ & $25.13 \pm 0.81^{\mathrm{fabc}}$ & $110.48 \pm 0.99^{\mathrm{ab}}$ & $2373 \pm 78.82^{\mathrm{abc}}$ & $10440 \pm 139.21^{\mathrm{bc}}$ \\
\hline 200 & $93.00 \pm 1.16^{b}$ & $16.93 \pm 0.64^{\mathrm{abcd}}$ & $7.12 \pm 0.46^{\mathrm{a}}$ & $24.05 \pm 0.81^{\text {fabcd }}$ & $109.55 \pm 0.99^{\mathrm{ab}}$ & $2236 \pm 78.82^{\text {bcd }}$ & $10186 \pm 139.21^{b c}$ \\
\hline
\end{tabular}

Table.2 Effect of silica nanoparticles on seed borne fungi

\begin{tabular}{|c|c|}
\hline $\begin{array}{c}\text { Concentrations } \\
\text { of SNPs }(\mathbf{p p m})\end{array}$ & $\begin{array}{c}\text { Infection level } \\
(\mathbf{\%})\end{array}$ \\
\hline $\mathbf{0}$ & $9.67 \pm 0.15^{\mathrm{b}}$ \\
\hline $\mathbf{2 5}$ & $9.44 \pm 0.15^{\mathrm{b} b}$ \\
\hline $\mathbf{5 0}$ & $8.83 \pm 0.15^{\mathrm{bc}}$ \\
\hline $\mathbf{7 5}$ & $8.00 \pm 0.15^{\mathrm{bcd}}$ \\
\hline $\mathbf{1 0 0}$ & $7.53 \pm 0.15^{\mathrm{bd}}$ \\
\hline $\mathbf{1 2 5}$ & $6.97 \pm 0.15^{\mathrm{b}}$ \\
\hline $\mathbf{1 5 0}$ & $6.17 \pm 0.15^{\mathrm{b}}$ \\
\hline $\mathbf{1 7 5}$ & $5.53 \pm 0.15^{\mathrm{b}}$ \\
\hline $\mathbf{2 0 0}$ & $5.13 \pm 0.15^{\text {b }}$ \\
\hline
\end{tabular}

Values indicates means \pm Standard Error, figures in the column followed by same letters are non-significant at $P \leq 0.01$ by Duncan's multiple range test. 
Figure.1 Average particle diameter of biosynthesized silica nanoparticles

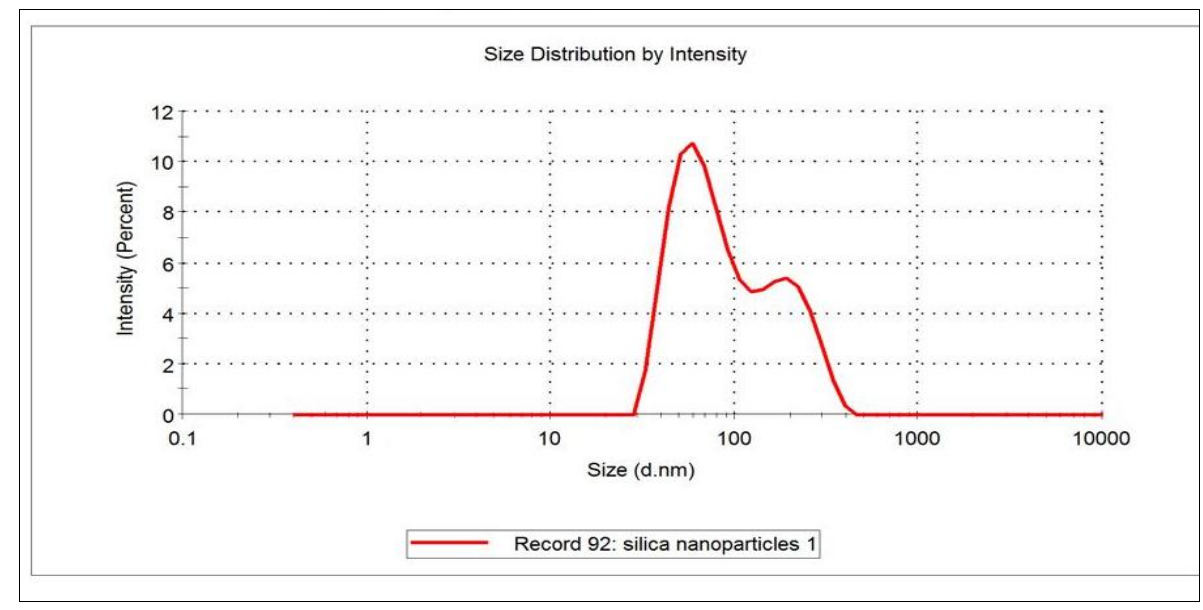

Figure.2 XRD pattern of biosynthesized silica nanoparticles

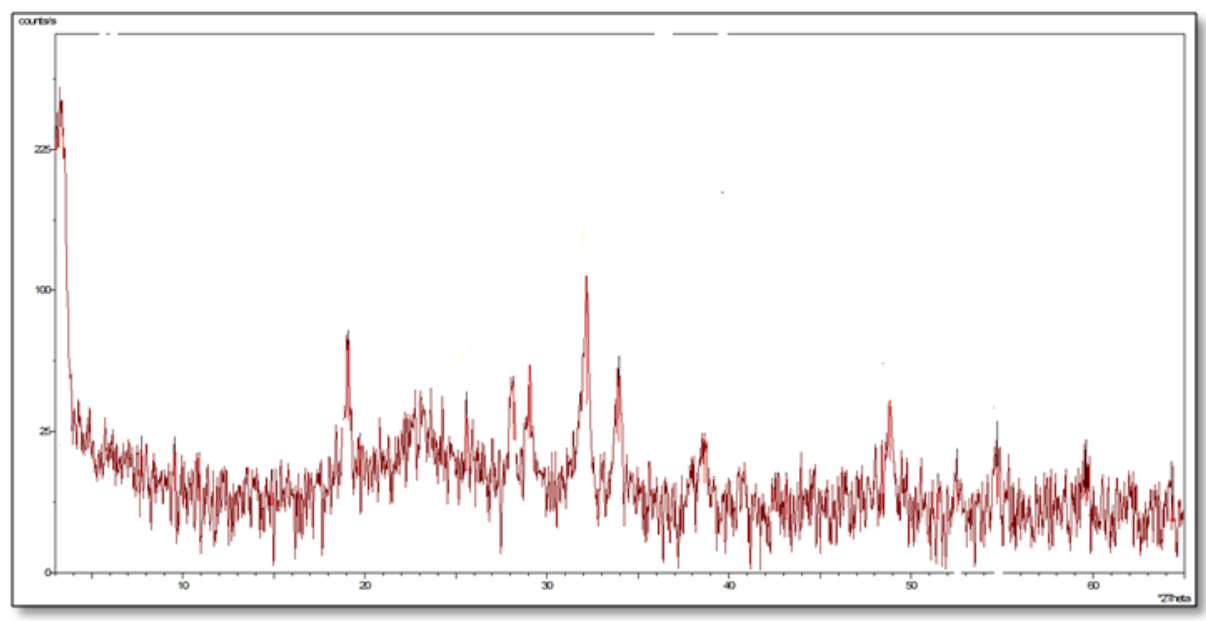

Figure.3 Effect of SNPs on peak value, speed of germination and mean germination time

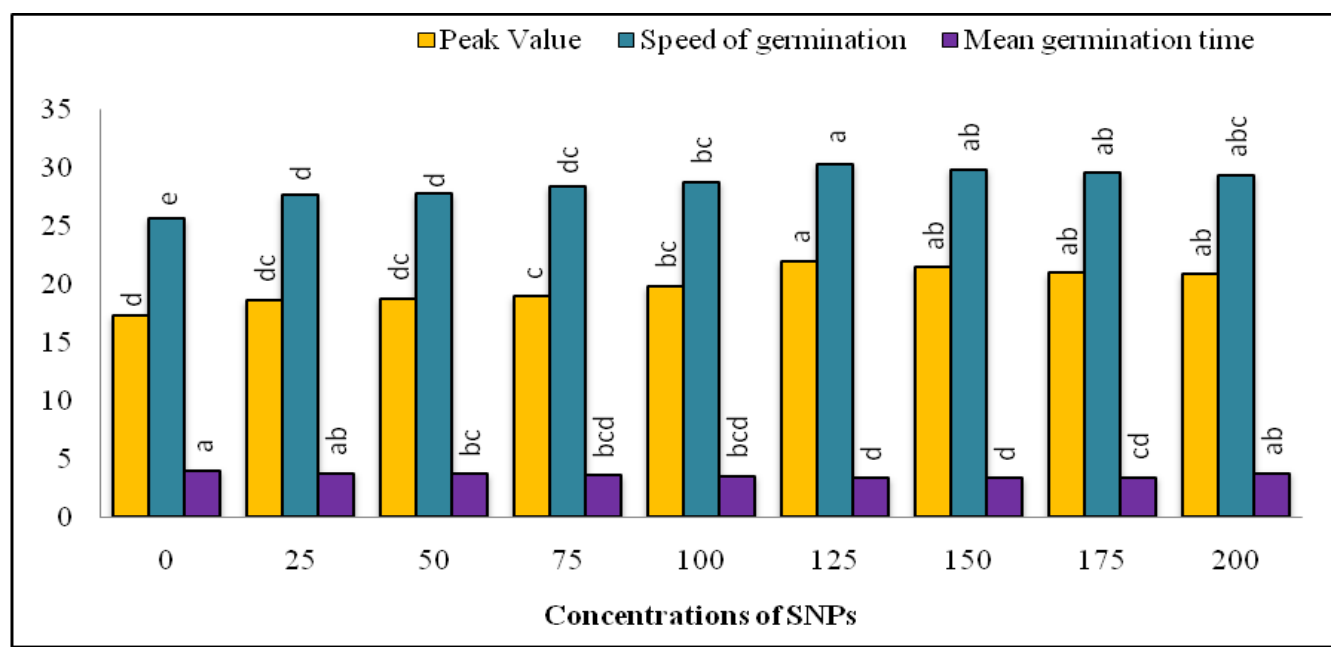




\section{Plate.1 SEM image of biosynthesized silica nanoparticles}

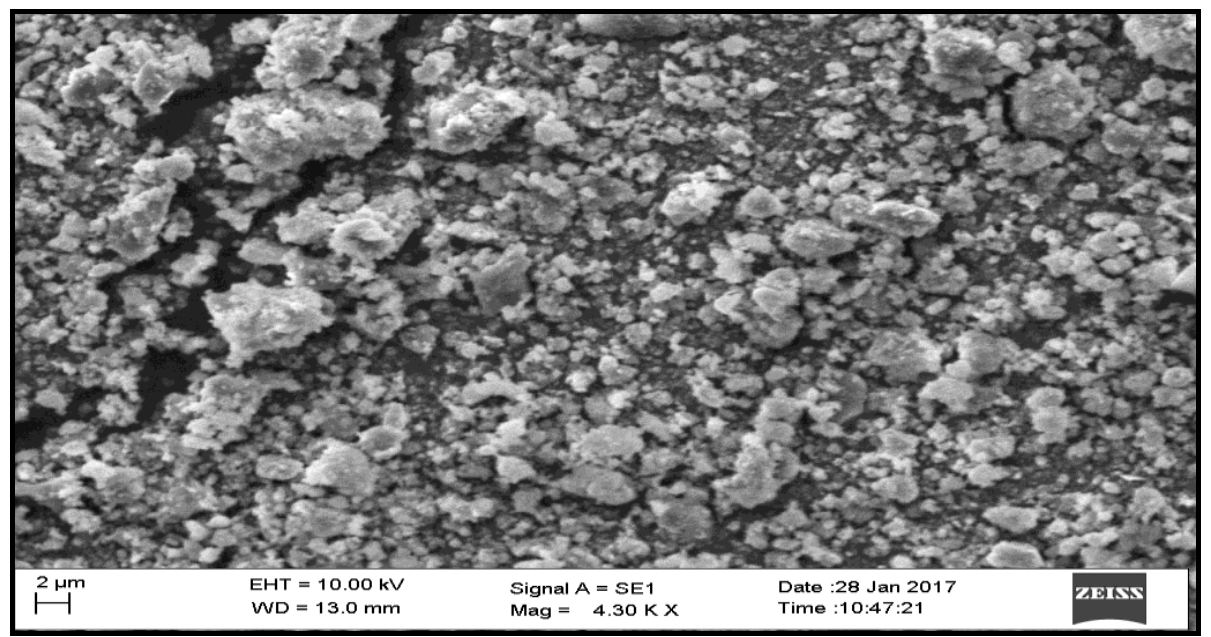

Effect of SNPs on peak value, speed of germination and mean germination time

The maximum peak value was recorded in 125 ppm of SNPs, which was $21.13 \%$ highest over control as presented in Figure 3. The control showed an average speed of germination in (25.69), while the concentration of $125 \mathrm{ppm}$ recorded highest speed of germination (30.40) but higher concentrations showed declined in speed of germination over the $125 \mathrm{ppm}$.

Lower mean germination time represents early seed germination. These results revealed that priming of rice seeds with $125 \mathrm{ppm}$ of SNPs, recorded lowest mean germination time (3.35 day), which reduced by $19.40 \%$ in comparison to the control. According to Feizi et al., (2013) activation of respiration and rapid ATP production appears to be the primary metabolic events induced by early seed germination. This could be ascribed to the increased synthesis and activity of hydrolytic enzymes during the early phases of germination and effective mobilization of the available food reserves in the seeds resulted in the early emergence and growth of the seedlings (Raju and Rai, 2017).

\section{Seed borne fungi}

The maintenance of seed quality during storage is very much essential. In this context, pathogens play a major role in determining the storage life of seed. The contamination of seeds due to seed borne fungi during storage reduces seed quality which affects on seed germination and establishment of seedling

Table 2 shows that, the level of seed pathogen infection decreased as concentration of SNPs increased ranged from 9.44 to 5.13 as against $9.67 \%$ in control. From identification the of seed borne fungi under stereo binocular microscope found that only Rhizopus oryzae was infected to all the treatments including control. The minimum seed pathogen infection levels observed in treatments with higher concentration at $200 \mathrm{ppm}$ and $175 \mathrm{ppm}$ of SNPs, which were $88.49 \%$ and $74.86 \%$ respectively, decreased over the control. It has been hypothesized that the capacity of silicic acid to form into a hard, glass like coating of polymerized $\mathrm{SiO}_{2}$, or plant opal, on the epidermal surfaces may physically block penetration by fungi (Wattanapayapkul et al., 2011). Therefore this might be due to the reason to reduce the level of seed pathogen infection in rice seed priming with SNPs. The 
results of this study are in good agreement with other studies done using nanoparticles to reduce the seed borne pathogens silver, titanium dioxide, zinc oxide and copper oxide observed in chilli (Kumar et al., 2016), silver and copper observed in cucumber (Ziedan and Saad, 2016).

In conclusion, the result of present study showed potential application of biosynthesized silica nanoparticles to encourage speed of seed germination, breaking seed dormancy and improve seed quality of rice. Significantly highest seed quality parameters viz per cent germination $(98.70 \%)$, root length $(18.25 \mathrm{~cm})$, shoot length $(7.57 \mathrm{~cm})$, seedling length $(26.09 \mathrm{~cm})$, seedling dry weight (112.20), seedling vigour index-I (2576), seedling vigour index-II (11079), peak value (22.00), speed of germination (30.40) and mean germination time (3.35 day) was recorded in $125 \mathrm{ppm}$ of SNPs. Increased in concentrations from 150 to $200 \mathrm{ppm}$ showed decrease in seed quality parameters over the superior treatment but positive effect over the control. Regarding the toxic levels, future studies should focus on levels of uptake and retention, the mechanism of phytotoxicity and uptake kinetics and interactions of SNPs within cells. Intensive, research at molecular level can be undertaken to understand the mechanism of entry of SNPs and their mode of action in invigorating the seeds during priming with nanoparticles that would help to increase the yield by improving seed quality.

\section{Acknowledgements}

The authors thank the University of Agricultural Sciences, Centre for Nanotechnology, Department of Processing and Food Engineering and Department of Seed Science and Technology, Raichur, Karnataka, India to provide the facility to carry out the experimental work and also thanks to Indian Council of Agriculture
Research (ICAR) for the financial support under National Talent Scholarship during research work.

\section{Compliance with Ethical Standards}

The authors declares that they have no conflict of interest.

\section{References}

Abdul-Baki, A., Anderson, J. D. (1973) Vigor determination in soybean seed by multiple criteria. Crop Science 13, 630633.

Adhikari, T., Kundu, S., Rao, A. S. (2013) Impact of $\mathrm{SiO}_{2}$ and Mo nanoparticles on seed germination of rice (Oryza sativa L.). International Journal of Agriculture Food Science and Technology 4, 809816.

Agarie, S., Hanaoka, N., Ueno, O., Miyazaki, A., Kubota, F., Agata, W., Kaufman, P. B., (1998) Effects of silicon on tolerance to water deficit and heat stress in rice plants (Oryza sativa L.) monitored by electrolyte leakage. Plant Production Science 1, 96-103.

Alam, S., Seth, R. K., Shukla, D. N. (2014) Screening of some fungi isolation of rice cultivars in different site of Allahabad, Varanasi, Mirzapur, Jaunpur and Chandauli district in Uttar pradesh. Journal of Agriculture and Veterinary Science 7, 67-71.

Asgedom, H., Becker, M. (2001) Effects of seed priming with nutrient solutions on germination, seedling growth and weed competitiveness of cereals in eritrea. In: Proc. Deutscher Tropentag, University of Bonn and ATSAF, Magrraf Publishers Press, Weickersheim. 282.

Azimi, R., Borzelabad, M. J., Feizi, H., Azimi, A. (2014) Interaction of $\mathrm{SiO}_{2}$ nanoparticles with seed prechilling on germination and early seedling growth 
of tall wheatgrass (Agropyron elongatum L.). Polish Journal of Chemical Technology 16,136-141.

Azimi, R., G. Heshmati, R. K. Habib, 2016. Evaluation of $\mathrm{SiO}_{2}$ nanoparticle effects on seed germination in Astragalussquarrosus. Journal of Rangeland Science 6, 139-143.

Castiglione, M. R., Giorgetti, L., Geri, C., Cremonini, R. (2011) The effects of nano- $\mathrm{TiO}_{2}$ on seed germination, development and mitosis of root tip cells of Vicianarbonensis L. and Zea mays L. Journal of Nanoparticle Research 13, 2443-2449.

Das, S. and N. Debnath, 2017. Effect of nanoparticles on plant growth and photosynthesis. International journal of advanced research in science, engineering and technology 6, 113-115.

Demir, I., Ermis, S., Mavi, K., Matthews, S. (2008) Mean germination time of pepper seed lots (Capsicum annuum L.) predicts size and uniformity of seedlings in germination tests and transplant modules. Seed Science and Technology 36, 21-30.

Deng, Y., Yuan, F., Feng, Z., Ding, T., Song, J., Wang, B. (2014) Comparative study on seed germination characteristics of two species of Australia saltbush under salt stress. Acta Ecologica Sinica 34, 337-341.

Dragisic, M. J., Bogdanovic, J. Maksimovic, V., Nikolic, M. (2007) Silicon modulates the metabolism and utilization of phenolic compounds in cucumber (Cucumis sativus L.) grown at excess manganese. Journal of Plant Nutrition and Soil Science 170, 739744.

Farooq, M., Basra, S. M. A., Hafeez, K. (2006) Seed invigoration by osmohardening in coarse and fine rice (Oryza sativa L.). Seed Science and Technology 34, 181-187.
Feizi, H., Kamali, M., Jafari, L., Moghaddam, P. R. (2013) Phytotoxicity and stimulatory impacts of nanosized and bulk titanium dioxide on fennel (Foeniculumvulgare Mill). Chemosphere. 91, 506-511.

Gairola, K. C., Nautiyal, A. R., Dwivedi, A. K. (2011) Effect of temperatures and germination media on seed germination of Jatropha Curcas Linn. Advanced Biomedical Research 2, 66-77.

Ghorbani, F., Sanati, A. M., Maleki, M., 2015. Production of silica nanoparticles from rice husk as agricultural waste by environmental friendly technique. Environmental Studies of Persian Gulf. $2,56-65$.

Harris, D. (1996) The effects of manure, genotype, seed priming, depth and date of sowing on the emergence and early growth of (Sorghum bicolor L.) moench in semi-arid botswana. Soil. Tillage. Res. 40, 73-88.

International Seed Testing Association (ISTA) (2013) International rules of seed testing. Seed Science and Technology 27, 25-30.

Janmohammadi, M., Sabaghnia, N. (2015) Effect of pre-sowing seed treatments with silicon nanoparticles on germinability of sunflower (Helianthus annuus). Botanica Lithuanica 21, 13-21.

Kasaai, M. R. (2015) Nanosized particles of silica and its derivatives for applications in various branches of food and nutrition sectors. J. Nanotechnol. 1-6.

Khan, M. R. and Rizvi, T. F. (2014) Nanotechnology: scope and application in plant disease management. J. Plant. Pathol. 13, 214-231.

Khot, L. R., Sankaran, S., Maja, J. M., Ehsani, E. W., Schuster, R., 2012. Applications of nanomaterials in agricultural production and crop protection: a review. Crop. Prot. 35, 6470. 
Korishettar, P., Vasudevan, S. N., Shakuntala, N. M., Doddagouda, S. R., Hiregoudar, S., Kisan, B. (2016) Seed polymer coating with $\mathrm{Zn}$ and Fe nanoparticles: an innovative seed quality enhancement technique in pigeonpea. J. Appl. Nat. Sci. 8, 445-450.

Kumar, G. D., Natarajan, N., Divya, M. (2016) Green synthesis and characterization of silver (Ag) nanoparticles using neem leaf extract and its antifungal ctivity against seed borne pathogens in chilli. Asian. J. Hort. 11, 109-113.

Lu, M. M. D., D. M. R. D, Silva, E. K, Peralta, A. N, Fajardo and Peralta, M. M. (2015) Effects of nanosilica powder from rice hull ash on seed germination of tomato (Lycopersiconesculentum). J. Appl. Res. Dev. 50, 11-22.

Maguire, J. D. (1962) Speed of germinationaid in selection and evaluation for seedling emergence and vigour. Crop. Sci. 2, 176-177.

Mahmoud, S.Y., Hosseny, M. H., EL-Shaikh, K. A. A., Obiadalla, A. H., Mohamed, Y. A. (2013) Seed borne fungal pathogens associated with common bean (Phaseolus vulgaris L.) seeds and their impact on germination. J. Environ. Stud. 11, 19-26.

Monica R. C., Cremonini, R. (2009) Nanoparticles and higher plants. Caryologia. 62, 161-165.

Nostro, A., Germano, M. P., Angelo, V. D., Marino, A., Cannatelli, M. A. (2000) Extraction methods and bioautography for evaluation of medicinal plant antimicrobial activity. Lett. Appl. Microbiol. 30, 379-384.

Rafiee, E., Shahebrahimi, S., Feyzi, M., Shaterzadeh, M. (2012) Optimization of and characterization of nanosilica produced from rice husk (common waste material). Int. Nano. Lett. 2, 2932.
Raju, B. B., Rai, P. K. (2017) Studies on effect of polymer seed coating, nanoparticles and hydro priming on seedling characters of pigeonpea (Cajanus cajan L.) seed. J. Pharmacogn. Phytochem. 6, 140-145.

Sahebi, M., Hanafi, M. M., Akmar, A., Rafii, M. Y., Azizi, P., Tengoua, F. F., Azwa, N. J., Shabanimofrad, M. (2015) Importance of silicon and mechanisms of biosilica formation in plants. Bio. Med. Res. Int. 7, 1-16.

Sahoo, S. K., Parveen, S., Panda, J. J. (2007) The present and future of nanotechnology in human health care. Nanomed. Nanotech. Biol. Med. 3, 2023.

Savant, N. K., Synder, G. H., Datnoff, L. E. (1997) Silicon management and sustainable rice production. Adv. Agron. 58, 151-199.

Senthilkumar, S., 2011. Customizing nanoparticles for the maintenance of seed vigour and viability in blackgram (Vigna mungo) cv. VBN 4., M.Sc. (Agri.) Thesis, TNAU, Coimbatore (India).

Sharifi-Rad, J. M., Sharifi-Rad, J. A. T., Silva 2016. Morphological, physiological and biochemical responses of crops (Zea mays L., Phaseolus vulgaris L.), medicinal plants (Hyssopus officinalis L., Nigella sativa L.), and weeds (Amaranthus retroflexus L., Taraxacum officinale $\mathrm{F}$. H. Wigg) exposed to $\mathrm{SiO}_{2}$ nanoparticles. J. Agr. Sci. Tech. 18, 1027-1040.

Shi, Y., Zhang, Y., Yao, H., Wu, J., Sun, H., Gong, H. (2014) Silicon improves seed germination and alleviates oxidative stress of bud seedlings in tomato under water deficit stress. Plant. Physiol. Biochem. 78, 27-36.

Siddiqui, M. H., Al-Whaibi, M. H. (2014) Role of nano-Sio 2 in germination of tomato (Lycopersicumesculentum seeds 
Mill.). Saudi. J. Biol. Sci. 21, 13-17.

Suriyaprabha, R.., Karunakaran, G., Yuvakkumar, R., Rajendran, V., Kannan, N. (2012) Silican nanoparticles for increased silica availability in maize (Zea mays L) seeds under hydroponic conditions. Curr. Nanosci. 8, 1-7.

Vithiya, K., Sen, S. (2011) Biosynthesis of nanoparticles. Int. J. Pharma. Sci. 2011, 2781-2785.

Wattanapayapkul, W., Polthanee, A., Siri, B., Bhadalung, N., Promkhambut, A. (2011) Effects of silicon in suppressing blast disease and increasing grain yield of organic rice in Northeast Thailand. Asian. J. Plant. Pathol. 5, 134-145.

Zheng, L., Hong, F., Lu, S., Liu, C. (2005.) Effect of nano- $\mathrm{TiO}_{2}$ on strength of naturally aged seeds and growth of spinach. Biol. Trace. Elem. Res. 104, 83-91.

Ziedan, E. H. E., Saad, M. M. (2016) Efficacy of nanoparticles on seed borne fungi and their pathological potential of cucumber. Int. J. Pharm. Tech. Res. 9, $16-24$.

\section{How to cite this article:}

Nita Babaso Patil, H. Sharanagouda, S.R. Doddagoudar, C.T. Ramachandra and Ramappa, K.T. 2018. Effect of Rice Husk Silica Nanoparticles on Rice (Oryza sativa L.) Seed Quality. Int.J.Curr.Microbiol.App.Sci. 7(12): 3232-3244. doi: https://doi.org/10.20546/ijcmas.2018.712.374 